\title{
Capital Markets Development and Borrowing Sources in Georgia
}

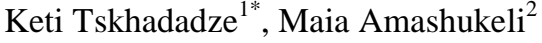

${ }^{1} \mathrm{PhD}$ Degree in Economics The University of Georgia, 0171, Georgia

${ }^{2}$ Head of the School of Business and Administrative Studies The University of Georgia, 0171, Georgia

\begin{abstract}
DOI: $10.36348 /$ sjef.2020.v04i08.007
| Received: 09.08.2020 | Accepted: 17.08.2020 | Published: 26.08.2020
\end{abstract}

*Corresponding author: Keti Tskhadadze

\section{Abstract}

The paper represents the challenges of Georgia's capital market, its importance for economic development and diversification of the financial sector. Capital markets have an increasing role and weight in Georgia's economy. The formation of the capital market is a long process as it requires the formation of the financial instruments, market infrastructure and institutions. Considering the capacity of economy and its potential benefits, Georgia has less developed economy and therefore, the capital market is underdeveloped. The paper analyzes the prerequisites for forming and developing the capital market in Georgia, as well as its characteristics. In this paper we investigate the several sources for financing gross financial needs and for making optimal decision, which type of instrument should the government of Georgia use before raising funds, we compare the financial conditions of the existing sources with each other.

Keywords: Borrowing Sources, Capital Market, Certificate of Deposits, Georgia, Treasury Securities.

JEL Classification: E44, E50, E60, F43, H74

Copyright @ 2020: This is an open-access article distributed under the terms of the Creative Commons Attribution license which permits unrestricted use, distribution, and reproduction in any medium for non-commercial use (NonCommercial, or CC-BY-NC) provided the original author and source are credited.

\section{INTRODUCTION}

The purpose of this paper is to analyze the trends and challenges of capital market development as its implications on economic growth of Georgia. An important precondition for the development of the capital market is the creation of a free and competitive environment in Georgia corresponding to its needs for capital and investment in the country, which will be efficient, innovative and in line with long-term plans of the country's economy. The development of the capital market plays an important role for sustainable economic growth in Georgia. As Georgia has an open economy, the capital market is the best way to attract foreign investments. Integration of capital markets has a positive impact on economic growth of Georgia and the main factors in which it positively affects economic growth are capital mobility, stock indices and portfolio investments [10]. In Georgia policymakers should pay significant attention in order to reduce external debt and encourage foreign investments for stimulating capital market development and growth.

In the paper we have presented several factors for securities market development, which affect the demand and supply sides. The supply side can be affected if the Georgian government decides to sell the shares of large companies at other country's stock market as it will have a negative effect on the supply at the Georgia's securities market. As for the demand side it can be pension system reform, as in that case accumulated finances will be invested to the securities market instruments [7, 8].

For financing gross financial needs there are several sources that government can use and we have made a comparison of loans from multilateral and bilateral creditors (MBCs), issuance of government securities on international market, issuance of government securities on domestic market. The loans from MBCs has the most important role in Georgia's total borrowing as it is mainly used for financing infrastructure rehabilitation and vital programs for country's development. Whenever domestic market is underdeveloped inflation expectations are overestimated and domestic borrowing becomes quite expensive, in that case financial resources raising funds on international market becomes another important option. As for the third important option we are presenting the significance of the issuance of government securities [11].

\section{Capital Market Trends and their Implications}

Capital markets have become an important feature of Georgia's economy that helps to attract capital, foreign investment and fosters financial 
innovation. For financing business and economy, besides direct investments, bank loans and securities market play a crucial role. The foundations of the securities market in Georgia took place in 1998-2000, but it is still not developed, as it is a complex mechanism and even a lack of a small part of the mechanism is sufficient to provoke the failure of the whole system. There are numerous factors that influence the functioning of the securities market (see Table N1). The security market's development was not being paid much attention and only in 2000-2007 it started to gradually gain strength [6].

Table-1: Securities Market Development Factors in Georgia

\begin{tabular}{|l|r|r|r|r|r|r|}
\hline & 2010 & 2011 & 2012 & 2013 & 2014 & 2015 \\
\hline Securities Market Legislation & & & & & & \\
\hline Securities Market Regulator & & & & & & \\
\hline Trading/clearing/Settlement Infrastructure & & & & & & \\
\hline Investment Banks/Brokerage Companies & & & & & & \\
\hline $\begin{array}{l}\text { Sustainability/Institutional Capacity of the } \\
\text { Securities market Infrastructure }\end{array}$ & & & & & & \\
\hline Government Securities & & & & & & \\
\hline Privatization Policy & & & & & & \\
\hline Institutional Investors & & & & & & \\
\hline Investment Funds & & & & & & \\
\hline Tax Policy & & & & & & \\
\hline General Investment Environment & & & & & & \\
\hline Macroeconomic Stability & & & & & \\
\hline Trust to Financial Institutions & & & & & \\
\hline Judiciary Independence and professionalism & & & & & & \\
\hline Corporate Governance & & & & & \\
\hline Public Awareness & & & & & \\
\hline
\end{tabular}

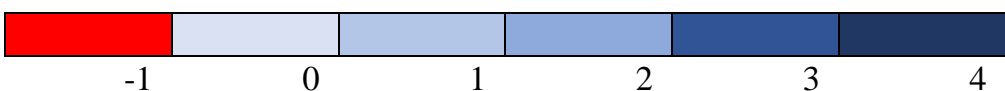

Source: www.idfi.ge

In the above mentioned Table N1 there are indicated several factors for securities market development. First of all, these factors affect the demand and supply sides. For example, the supply side is affected by the following factors: if the Georgian government decides to sell the shares of large companies at other country's stock markets it will definitely have a negative effect on the suply at the Georgia's securities market, as well as public offerings in Georgia will increase the supply of securities in Georgia. Factors influencing the demand side can be the following: pension system reform, which will assure that the pension funds will invest their accumulated finances to the securities market instruments; return of trades of the listed securities to the competitive public environment will result in increase on the demand side.

The securities market destruction was directly linked to the lobbying the biggest banking group and independent state regulator was abolished. Afterwards the overseeing function of the securities market was passed to the National Bank of Georgia (NBG), whose primary task is to develop a competitive banking system.

The Georgian security market is presented by certificate of deposits, treasury securities (treasury bills and treasury bonds), corporate bonds and stocks. The certificate of deposits are instruments used by the NBG for open market operations, with durations such as 3 or 6 months and has been issued by the NBG since 2006 . These types of securities are sold through auctions using multiple pricing methods and only commercial banks have the right to participate in the auction. Through certificate sof deposit, the NBG removes medium-term liquidity from the capital market $[9,12]$. 


\section{Diagram-1: Volume of Certificate of Deposits in Circulation, GEL Millions}

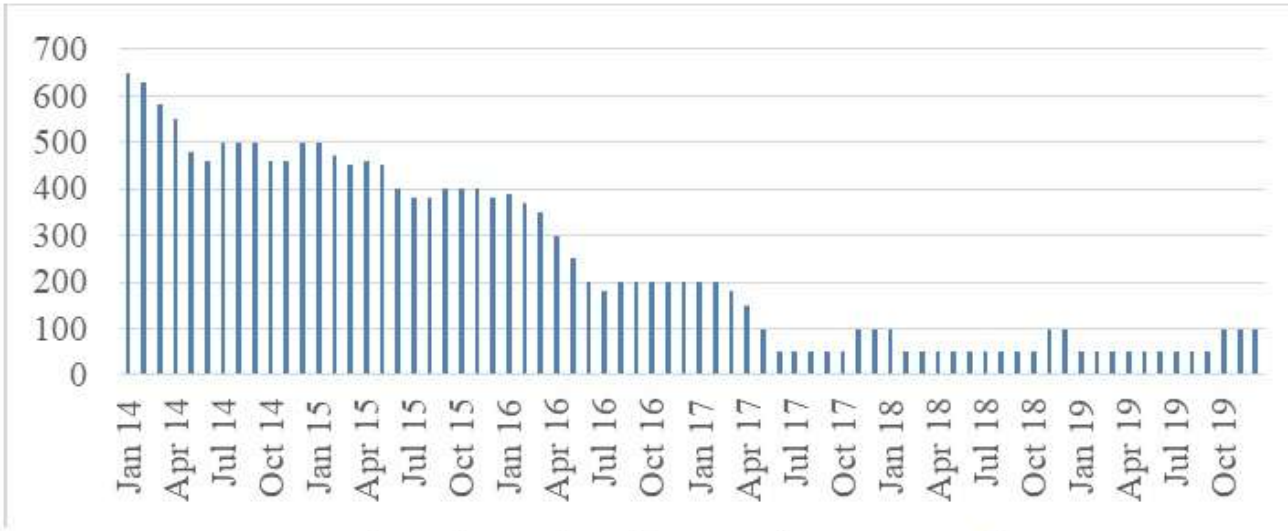

Source: National Bank of Georgia, www.nbg.gov.ge

In 2019, the NBG issued a 3-month deposit certificates, which was used by the banking sector as an attractive and effective tool for managing liquidity. Overall in all 13 auctions conducted by the NBG in 2019, commercial banks purchased the total amount of the certificates of deposits. The nominal amount of allotment was equal to 260 million Gel and exactly 260 million GEL was redeemed in 2019 (see Diagram N1). At the end of the year the stock of the NBG's cetificate of deposits equaled 80 million GEL that was held by six commercial banks.

In terms of government bonds, as of December 2019, the NBG held government bonds wich was worth of 152 million GEL that wasn't used for open market operations during the year.

For further development of the Georgian Lari money market, it was crucial that the ministry of finance of Georgia increased the issuance of government securities. In 2019, the ministry of finance issued 6 months and 1 year discount securities and 2,5 and 10 years coupon bonds. The discount securities are denominated in the national currency and the nominal value is 1,000 GEL. In 2019, 53 auctions were conducted and 2.34 billion GEL worth of securities were issued. In 2019 there were 14 commercial banks and non-banking investors that held 3.81 billion GEL securities in circulation [7].

It is worth mentioning that the value of treasury securities remains small in circulation relative to the size of the economy. In order to increase market liquidity the government has issued 2, 5 and 10 years benchmark bonds. Treasury securities are of high importance for ensuring budget revenues as well as for developing the Georgian money market (see Diagram N2).

Diagram-2: Volume of Treasury Securities, GEL Millions

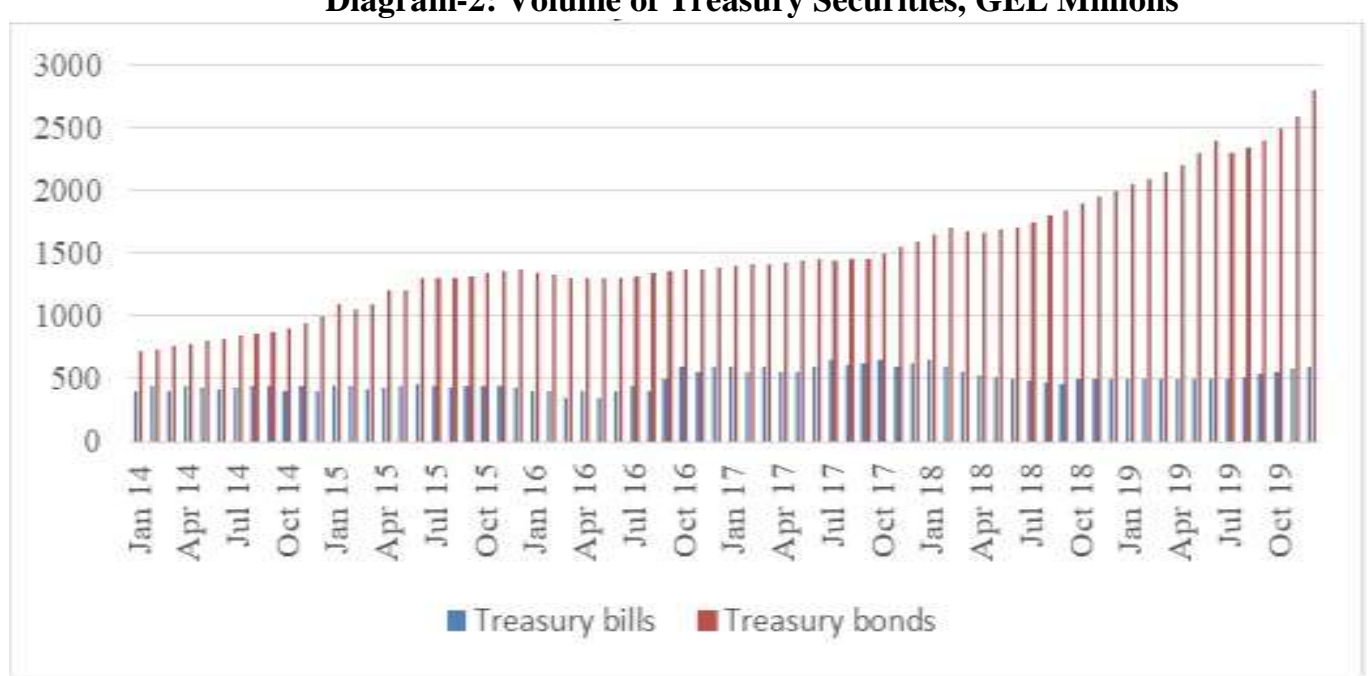

Source: National Bank of Georgia, www.nbg.gov.ge

Due to the stable macroeconomic environment, attractive interest rates on Georgian Lari, acceptable level of the financial market development and due to the modern infrastructure the interest of non-resident investors has increased in the treasury securities market. The market infrastructure on the securities market therefore provide a good basis for intensifying activities on the secondary market for securities $[5,7]$. 
Despite the recent growth trends in certain areas, it is important to note that the securities market in Georgia is still underdeveloped. The reasons for this can be the low level of financial education, lack of incentive tax policy for companies and the factor of competition in the banking sector. For developing the securities settlement system, Georgia launched the Securities Settlement System (GSSS), which offers a comprehensive set of the highest quality services to both domestic and international participants $[4,7]$. The system helps the securities transactions to become fast, convenient, riskless and cheaper. The system also helps to automate solutions for operations such as the issue of securities, secondary market transactions, corporate actions and redemptions.

For developing the capital market in Georgia it is important to separate the banking sector and the stock market, restrict commercial banks from owning institutions that make up the securities market infrastructure. The existence of a separate securities market supervision from the NBG must be also restricted.

If the government of Georgia's will to implement capital market reform is in place, there are several steps that has to be done to accomplish the goal: first of all, there is a need to establish the important norms, which can be achieved by amending the law on securities market. Secondly, the harmonization needs to be achieved between the securities market of Georgia with the EU directives and other international standards. Elimination control of banks over the securities market infrastructure, stock exchange, central securities depositary and instead, introducing the mechanisms of ownership diversification can play an important role to increase the trust of investors and issuers. Introduction of the pension reform can also entail investment of significant part of the accumulated capital in Georgian Economy.

\section{Borrowing Sources}

The role of capital markets is increasing in the financial system of Georgia. Economic and financial integration helps companies to access competitive capital markets and therefore accelerate the economic development. Government can use several sources for financing gross financial needs, such as loans from multilateral and bilateral creditors (MBCs), issuance of government securities on international market, issuance of governmetn securities on domestic market.
Loans from MBCs takes the most important part in Georgia's total borrowing. The loans from foreign sources are used for financing infrastructure rehabilitation and vital programs for country's development. During 2018 year 1, 379.8 mln GEL was borrowed from MBCs, out of which 924,8 mln GEL were project loans and $455 \mathrm{mln}$ GEL government reforms supporting loans [14].

For obtaining financial resources raising funds on international market is another important option, as whenever domestic market is underdeveloped inflation expectations are overestimated and domestic borrowing becomes quite expensive. At this time government can attract financial resources and it becomes crucial to increase Georgia's awareness on the international capital market.

The third important option for obtaining financial resources is the issuance of government securities, which has to be consistent with prudent degree of risks and government securities in Georgia should be developed even further. Nowadays, the major buyers of government securities are a relatively small group of commercial banks and for developing domestic market there is a need to attract mutual funds, pension funds, private domestic and foreign investors. Selling significant amount of government securities for investors is not easy in Georgia, as there is a low liquidity on the market. If the total issuance of the securities will increase it will result in also increased demand from foreign investors that will decrease interest rates and reduce risks associated with the repayment of debt $[3,5,13]$.

In order to make optimal decision, which type of instrument should the government of Georgia use before raising funds, it is important to compare the financial conditions of the existing sources with each other.

When comparing the conditions of borrowing from MBCs to domestic borrowing, it may seem that borrowing from $\mathrm{MBCs}$ is relatively cheaper than borrowing from the domestic market, but apart from the interest rates, we must not forget to compare other factors such as exchange rate risk and sterilization cost (see Table N2). 
Table-2: Relative Advantages of Financing Sources

\begin{tabular}{|c|c|c|c|}
\hline & $\begin{array}{c}\text { Loans from } \\
\text { Multilateral and } \\
\text { Bilateral Creditors }\end{array}$ & $\begin{array}{c}\text { Issuance of Government } \\
\text { Securities on International } \\
\text { Market }\end{array}$ & $\begin{array}{c}\text { Issuance of Government } \\
\text { Securities on Domestic } \\
\text { Market }\end{array}$ \\
\hline Refinancing Risk & Low & High & Low \\
\hline Interest Rate Risk & Medium & & Low \\
\hline $\begin{array}{c}\text { Absence of Exchange Rate } \\
\text { Risk }\end{array}$ & & $\checkmark$ & $\checkmark$ \\
\hline $\begin{array}{c}\text { Absence of Crowding-out } \\
\text { Effect }\end{array}$ & $\checkmark$ & $\checkmark$ & \\
\hline Concessional Terms & $\checkmark$ & & $\checkmark$ \\
\hline $\begin{array}{c}\text { Impact on Increase of } \\
\text { Official Reserves of Country }\end{array}$ & $\checkmark$ & $\checkmark$ & $\checkmark$ \\
\hline $\begin{array}{c}\text { Absence of Restrictions Due } \\
\text { to Regulations }\end{array}$ & & & $\checkmark$ \\
\hline $\begin{array}{c}\text { Facilitate the development of } \\
\text { Capital Market }\end{array}$ & & & \\
\hline $\begin{array}{c}\text { Risk-free Investing } \\
\text { Opportunities in GEL for } \\
\text { Institutional Investors }\end{array}$ & & & \\
\hline $\begin{array}{c}\text { Increase of Awareness on } \\
\text { International Markets }\end{array}$ & & & \\
\hline
\end{tabular}

Source: Ministry of Finance of Georgia, www.mof.ge

It should be noted that borrowing in local currency, unlike financing from external sources is not characterized by the exchange rate risk, so it is better to reduce the share of foreign debt in the government debt portfolio and increase the share of loans denominated in national currency. Given this, it is clear that borrowing in the local market is non-inflationary by nature. Largescale borrowings in the local market will not reduce lending to the private sector, vice versa, it will develop the government securities market, which will increase the liquidity of domestic debt instuments, the maturity of GEL denominated loans will also increase and interest rates that cause increment in demand on loans will decrease $[2,15]$.

\section{CONCLUSION}

It is important for Georgia to begin implementing its own legislation in the capital market. Georgian legislation should be introduced for small investors in order to protect the ones that are tailored in this category. Overall, the development of the capital market ensures the promotion of capital market in Georgia, diversification of the financial system, increasing sustainability towards financial sector shocks and increasing access to long-term investment resources [1]. The developed infrastructure of the capital market is one of the most essential conditions as it promotes trade and information exchange.

Despite the growth trends in certain areas the securities market in Georgia is still underdeveloped and the reasons for this can be the low level of financial education, lack of incentive tax policy for companies and the factor of competition in the banking sector. For developing the securities settlement system, Georgia launched the Securities Settlement System (GSSS), which offers a comprehensive set of the highest quality services to both domestic and international participants.

After comparing the several sources for financing gross financial needs, it became clear that borrowing from MBCs is cheaper than borrowing from the domestic market. Borrowing in local currency, unlike financing from external sources is not characterized by the exchange rate risk, so it is better to reduce the share of foreign debt in the government debt portfolio and increase the share of loans denominated in national currency.

\section{REFERENCES}

1. Abuselidze, G. (2018). Georgia's Capital Market: Functioning Problems and Development Directions in Association with European Union. Abuselidze, $G, 1929-1938$.

2. Alan, S., Hussein, D. (2019). The impact of capital market on the economic growth in Oman. Financial Studies, 2, 115-129.

3. Brasoveanu, L. O., Dragota, V., Catarama, D., \& Semenescu, A. (2008). Correlations Between Stock Market Development and Economic Growth. Journal of Economic Development, 29(1), 33-50.

4. Doghonadze, I. (2016). Influence of Monetary Policy on government securities market (on the example of Georgia). Journal "Economisti", N2, 118-133. Tbilisi

5. Fesiashvili, C. 2017. Capital Market development in Georgia; Georgia's Stock Exchange Available at: https://www.saras.gov.ge/Content/files/GSE- 
Capital-Market-Development-FINAL-ENG19.06.17.pdf

6. Loladze. G. (2015). Securities Market in Georgia Problems, Challenges and Perspectives. Institute for Development of Freedom of Information.

7. National Bank of Georgia. (2019). Annual Report.

8. National Bank of Georgia. (2018). Annual Report.

9. Nuhiu, A., Hoti, A. (2011). Effects of capital markets development on economic growrh of Western Balkan countries. European Journal of Economics, 43, 88-98.

10. Oprea, O., Stoica, O. (2018). Capital markets integration and economic growth. Montegrin Journal of Economics, 14(3), 23-35.
11. Tokmazishvili, M. (2019). Capital market challenges and development prerequisites in Georgia. Globalization and Business, 8, 60-67

12. Lenee, T. L., \& Oki, J. (2017). Capital market development and economic growth: Evidence from the MINT countries. Journal of Economics and Sustainable Development, 8(2), 68-107.

13. Vazakidis, A., \& Adamopoulos, A. (2009). Stock market development and economic growth. American Journal of Applied Sciences, 6(11), 1932.

14. www.mof.ge - Ministry of Finance of Georgia

15. www.nbg.gov.ge - National Bank of Georgia. 